medRxiv preprint doi: https://doi.org/10.1101/2020.05.04.20090282; this version posted May 8,2020 . The copyright holder for this preprint

(which was not certified by peer review) is the author/funder, who has granted medRxiv a license to display the preprint in perpetuity.

All rights reserved. No reuse allowed without permission.

\title{
Results from the first South African Health Products Regulatory Authority-approved randomised trial evaluating supplementation of standard antibiotic therapy with a commercially available probiotic in South African women with bacterial vaginosis
}

Anna-Ursula Happel ${ }^{1}$, Ravesh Singh, ${ }^{2,3}$ Nireshni Mitchev, ${ }^{2}$ Koleka Mlisana, ${ }^{2,3}$ Heather B. Jaspan, ${ }^{1,4}$ Shaun L. Barnabas, ${ }^{* 1,5}$ Jo-Ann S. Passmore*1,3,7

${ }^{1}$ Institute of Infectious Disease and Molecular Medicine, University of Cape Town, Cape Town, South Africa; ${ }^{2}$ School of Laboratory Medicine and Medical Sciences, University of Kwa-Zulu Natal, Durban, South Africa; ${ }^{3}$ National Health Laboratory Service, South Africa; ${ }^{4}$ Seattle Children's Hospital, Seattle, USA; ${ }^{5}$ Family Clinic Research Unit, Stellenbosch University, Tygerberg, South Africa; ${ }^{6}$ NRF-DST CAPRISA Centre of Excellence in HIV Prevention, Cape Town, South Africa

*Shaun Barnabas and Jo-Ann Passmore are co-last authors and contributed equally to the study

Address correspondence to Dr Anna-Ursula Happel, Institute of Infectious Disease and Molecular Medicine, Division of Medical Virology, Faculty of Health Sciences, University of Cape Town, Anzio Road, Observatory 7925, Cape Town, South Africa. Phone: +27-214066823; E-mail: anna.happel@uct.ac.za 
medRxiv preprint doi: https://doi.org/10.1101/2020.05.04.20090282; this version posted May 8,2020 . The copyright holder for this preprint

(which was not certified by peer review) is the author/funder, who has granted medRxiv a license to display the preprint in perpetuity.

\section{Abstract [339 words]}

Background: Bacterial vaginosis (BV) increases HIV risk and adverse reproductive outcomes in women. The standard-of-care (SOC) for BV is antibiotic treatment; however, cure rates are low and recurrence frequent. In South Africa, no trial comparing probiotics to SOC for BV has been approved by the South African Health Products regulatory Authority (SAHPRA). We aimed to explore the South African regulatory and ethics environment to evaluate adjunctive probiotics for improvement of $\mathrm{BV}$ treatment in a randomized single-blinded trial of a locally sourced oral-vaginalcombination probiotic for vaginal health.

Methods: South African women with symptomatic vaginal discharge were screened for BV and sexually transmitted infections (STIs) including Trichomonas vaginalis, Mycoplasma genitalium, Neisseria gonorrhoae and Chlamydia trachomatis. BV positive (by Nugent Scoring) STI negative women were randomized to Metrogel $^{\mathrm{TM}}$ alone $(n=12)$ or Metrogel ${ }^{\mathrm{TM}}$ followed by a commercially available South African oral/vaginal probiotic (Vagiforte PLUS ${ }^{\circledR}$ Combo Pack; n=18). BV cure at one month was the primary endpoint. Secondary endpoints were recurrence, symptoms, vaginal microbiota and genital inflammation over five months post-treatment, and acceptability of the administered probiotic.

Results: SAHPRA reviewed and acknowledged this trial. Overall, $44.8 \%$ of women cleared BV one month post-treatment. Despite confirmed viability of probiotic species contained in the commercial oral/vaginal probiotic, they did not appear to colonize the female genital tract of most women in the intervention group. No significant differences in $\mathrm{BV}$ cure rates, vaginal $\mathrm{pH}$, microbiota nor IL-1 $\alpha$ concentrations were found between SOC and intervention groups, although we were underpowered to detect small differences. Acceptability and adherence to the probiotic product was high.

Conclusion: Navigation of the SAHPRA registration process for evaluating a commercial probiotic in a randomised trial has laid the path for future trials of improved probiotic products for vaginal health in South Africa with adequate sample sizes. Acceptability of vaginally applied probiotics was high in South African women. 
Improvements in both the content and delivery of commercially available probiotic products for vaginal health should be considered.

Trial registration: This trial was registered on 17 October 2017 with the South African National Clinical Trial Register of the Department of Health (DOH-27-1117-5579).

Keywords: BV, probiotics, female genital tract, vaginal health, South Africa, SAHPRA 
medRxiv preprint doi: https://doi.org/10.1101/2020.05.04.20090282; this version posted May 8, 2020. The copyright holder for this preprint (which was not certified by peer review) is the author/funder, who has granted medRxiv a license to display the preprint in perpetuity.

\section{Background}

Globally, bacterial vaginosis (BV), a polymicrobial dysbiosis of the vagina, is the most common genital condition of women of reproductive age (1), and increases risk of adverse pregnancy outcomes $(2,3)$ and acquisition and transmission of sexuallytransmitted infections (STIs), including $\operatorname{HIV}(4,5)$, possibly due to the associated genital inflammation (6). Antibiotics such as metronidazole and clindamycin remain the standard of care (SOC) for treating BV, although it is estimated that more than $50 \%$ of women experience recurrent episodes within 6-12 months $(7,8)$. Most countries treat $\mathrm{BV}$ as part of syndromic management (9), although $>85 \%$ of $\mathrm{BV}$ cases are asymptomatic while still being associated with significantly elevated genital inflammatory cytokine profiles (10). In Africa, where epidemics of BV, STIs and HIV converge (11) and genital inflammation associated with even asymptomatic BV may increase HIV risk $(5,12)$, an urgent need to rethink and improve the SOC for treating BV exists.

Several clinical studies have evaluated Lactobacillus-containing probiotics as an adjunct to antibiotics in treating BV $(13,14)$. However, there is clinical equipoise as to whether adjunctive probiotics improve BV cure and/or recurrence rates, as a recent meta-analysis (15) concluded that adjunctive probiotics may improve BV cure rates but that there is currently not enough high-quality clinical evidence to support this approach as superior to antibiotic treatment alone. While randomized controlled trials (RCTs) assessing the effects of probiotics on BV management have been performed in several African countries $(16,17)$, only one exploratory pilot study has recently been performed in South Africa (18). As the microbial composition of the lower female genital tract (FGT) in health and dysbiosis may be influenced by regional factors, including diet, vaginal insertion, hygiene practices and possibly host genetics (19-21), it is important to conduct such trials in South African women to evaluate the effectiveness of probiotics for vaginal health in a local context.

Recently, we surveyed $>100$ commercially-available probiotics currently on the market in South Africa as over-the-counter (OTC) products, of which only four were indicated for vaginal health and only one was intended for vaginal application (22). Although in South Africa the registration of medicines, probiotics and health supplements along with their use in clinical trials is regulated by the South African Health Product Regulatory Authority (SAHPRA), none of these OTC probiotics had been formally 
medRxiv preprint doi: https://doi.org/10.1101/2020.05.04.20090282; this version posted May 8,2020 . The copyright holder for this preprint (which was not certified by peer review) is the author/funder, who has granted medRxiv a license to display the preprint in perpetuity.

reviewed by SAHPRA and no trial evaluating the impact of probiotics on health outcomes had previously been SAHPRA-approved or -acknowledged.

We therefore aimed to test the South African regulatory environment for evaluating vaginal probiotics in clinical trials using a locally sourced OTC product - Vagiforte ${ }^{\circledR}$ PLUS Combo Pack. This probiotic was the only local product administered orally as well as vaginally and was intended for a prolonged treatment duration of 15 days. This single-blinded, randomized trial enrolled symptomatic BV positive South African women to compare vaginal metronidazole gel treatment alone (SOC) to a combination of metronidazole and the locally manufactured oral/vaginal probiotic, with BV cure being the primary endpoint. Secondary endpoints included adherence, acceptability and preference of the probiotic, and the changes in vaginal $\mathrm{pH}$, symptoms and vaginal cytokine concentrations (interleukin [IL]-1 $\alpha$ ), as well as durability of any effect three and five months post-treatment. Changes in the vaginal concentrations of beneficial Lactobacillus spp. and non-optimal bacterial spp. (including Gardnerella vaginalis, Prevotella bivia, Bacterial Vaginosis-Associated Bacterium 2 (BVAB2), Megasphaera 1 and Atopobium vaginae) and evidence of vaginal colonization of the bacterial species contained in the administered probiotic were also evaluated. This first SAHPRAregistered probiotic trial intended to lay the foundation for future testing of novel or optimized probiotic products for BV management in South African women in RCTs with adequate sample sizes. 
medRxiv preprint doi: https://doi.org/10.1101/2020.05.04.20090282; this version posted May 8, 2020. The copyright holder for this preprint (which was not certified by peer review) is the author/funder, who has granted medRxiv a license to display the preprint in perpetuity.

\section{Methods}

Regulatory approval: Prior to conducting this trial, discussions with SAHPRA authorities were initiated in March 2016 and key areas that needed addressing were identified, including a decision on whether a notification or full application for the trial was necessary. Typically, the regulator requires full applications for products not registered in South Africa; or for those not being used for their registered indication, dose, or formulation. Alternatively, SAHPRA notification is required for phase IV clinical studies of an approved medication within its approved dosage, formulation and indication. SAHPRA confirmed that the trial did not require a full application as the product was already available OTC in South Africa, thus a notification application was submitted to SAHPRA and approved (SAHRPA Ref 20161201; PI: S. Barnabas).

Eligibility criteria: Women were recruited from a South African public sector STI clinic (Spencer Road Clinic) and from the UCT Student Wellness Centre in Cape Town, South Africa. Eligible women were 18-45 years old and seeking care for vaginal discharge. All eligible women were tested for BV (by Nugent scoring) and STIs, including C. trachomatis, N. gonorrhoea, T. vaginalis, and M. genitalium by TaqMan ${ }^{\circledR}$ Assays (Fast Track Diagnostics). Inclusion criteria were being BV positive (Nugent 710) but negative for any STI. Exclusion criteria included being pregnant, breastfeeding, pelvic inflammatory disease, living with HIV, having a known allergy to metronidazole, and/or currently using any other antibiotics or natural remedies in the urogenital area. Women who acquired an STI or had recurrent BV over the course of the trial were referred for treatment but not excluded, and any concomitant medication (including antibiotics) taken over the course of the study was recorded. Study visits were planned such that women were not menstruating nor reported having unprotected sex or douching in the 48 hours prior to sampling. All women were tested for HIV (Rapid Anti-HIV (1\&2) test; InTec products, Inc., China) and pregnancy (hCG Pregnancy test; Homemed ${ }^{\mathrm{TM}}$, South Africa) at screening.

Randomisation and blinding: Randomisation was performed using the pseudorandom number generator in Microsoft Excel 2016 (MT19937) by research pharmacists at the UCT CRC who were not involved with clinical procedures and/or screening processes and only dispensed the investigational product. Researchers and laboratory staff involved in sample and data analysis were blinded to the randomisation process. The 
medRxiv preprint doi: https://doi.org/10.1101/2020.05.04.20090282; this version posted May 8, 2020. The copyright holder for this preprint (which was not certified by peer review) is the author/funder, who has granted medRxiv a license to display the preprint in perpetuity. All rights reserved. No reuse allowed without permission.

research nurse who conducted the clinic visits was not blinded as she interacted directly with participants. After the database lock and a primary blinded analysis, the unblinded treatment allocations were released.

Dosing regimens: Eligible women either received topical metronidazole only $(0.75 \%$ gel, $5 \mathrm{~g}$ vaginally, once a day for 5 days; MetroGel $^{\mathrm{TM}} \mathrm{V}$, iNova Pharmaceuticals, South Africa, SOC group) or topical metronidazole followed by a 15-day treatment course of Vagiforte ${ }^{\circledR}$ PLUS Combo Pack (Bioflora, South Africa, Lot \# 21918; intervention group), which included five days of oral probiotic capsules followed by ten days of oral capsules together with twice daily vaginal spray. Vagiforte ${ }^{\circledR}$ PLUS oral capsules and each metered dose of the vaginal spray contained lyophilized L. acidophilus, $L$. rhamnosus $G G, B$. bifidum and B. longum at $\geq 2 \times 10^{9}$ colony-forming units (CFU).

Laboratory quality control of Vagiforte ${ }^{\circledR}$ PLUS lot used in the study: The contents and concentrations of each microbial species of Vagiforte ${ }^{\circledR}$ PLUS Combo Pack Lot \#21918 were confirmed prior to initiation of the trial (Additional Figure 1). Briefly, one full oral or vaginal dose was dissolved in Brain Heart Infusion broth (supplemented with $0.1 \%$ starch and $1 \%$ yeast, sBHI), serially diluted and plated in triplicates onto sBHI agar plates. Plates were incubated at $37^{\circ} \mathrm{C}$ for 48 hours under anaerobic conditions (using Oxoid ${ }^{\mathrm{TM}}$ AnaeroGen ${ }^{\mathrm{TM}}$ 2.5L Sachets, Thermo Fisher Scientific Inc., USA). The CFU per well were counted and the average concentration per dose was calculated. Contents were confirmed by MALDI-TOF (MALDI Biotyper, Bruker Daltonik, USA).

Clinical procedures and sample collection: At screening, a vulvo-vaginal swab for STI testing and a posterior fornix and lateral wall swab to screen for BV by Nugent Scoring were collected. At enrolment (pre-treatment), and one, three and five months posttreatment, genital samples were collected in the following order under speculum examination: (1) a vulvo-vaginal swab for STI testing; (2) a posterior fornix and lateral wall swab to screen for BV (by Nugent Scoring) and to measure vaginal $\mathrm{pH}$ (using a colour-fixed indictor pH strip; Macherey Nagel); and (3-4) two lateral wall swabs to measure genital IL-1 $\alpha$ (as marker of genital inflammation, by ELISA) and vaginal microbiota (by qPCR). In addition, women completed a questionnaire on demographics, reproductive health and sexual behaviour at enrolment, and a questionnaire assessing feasibility, acceptability and adherence to the administered 
medRxiv preprint doi: https://doi.org/10.1101/2020.05.04.20090282; this version posted May 8, 2020. The copyright holder for this preprint (which was not certified by peer review) is the author/funder, who has granted medRxiv a license to display the preprint in perpetuity. All rights reserved. No reuse allowed without permission.

products, vaginal symptoms and adverse events at follow up visits. Product preference was assessed at the final visit by questionnaire. Adherence was measured by self-report in medication diaries and questionnaires, as well as return of empty packages at the one-month follow-up visit.

Testing for STIs and $\boldsymbol{B V}$ : The commercial TaqMan ${ }^{\circledR}$ FTD STD9 (Fast Track Diagnostics, Luxembourg) kit, performed as per manufacturer's instructions, was used to test for $N$. gonorrhoeae, C. trachomatis, T. vaginalis and M. genitalium. As positive controls, genomic DNA extracts from the following ATCC ${ }^{\circledR}$ strains were included: $N$. gonorrhoeae (ATCC ${ }^{\circledR}$ 700825), C. trachomatis (ATCC ${ }^{\circledR}$ VR-885), T. vaginalis (ATCC $^{\circledR}$ 30001) and M. genitalium (ATCC $\left.{ }^{\circledR} 33530\right)$. BV was diagnosed by Gram staining of vaginal smears and Nugent Scoring. Slides were assessed microscopically and assigned a score between 0 and 10, with a score of 0-3 considered BV negative, 46 intermediate microbiota, and 7-10 BV positive.

Quantitative measurement of vaginal bacterial concentrations: To assess changes in the vaginal microbiota, vaginal concentrations of common vaginal Lactobacillus spp. (including L. crispatus, L. jensenii, L. iners, L. gasseri, L. vaginalis, L. mucosae), BVassociated organisms (including G. vaginalis, P. bivia, BVAB2, Megasphaera 1 and A. vaginae), and bacterial species contained in the administered probiotic product (including L. acidophilus, L. rhamnosus, B. bifidum and B. longum) were assessed using commercially available Applied Biosystems ${ }^{\mathrm{TM}}$ TaqMan ${ }^{\circledR}$ Assays (Thermo Fisher Scientific Inc., USA; Assay IDs Ba04646245_s1, Ba04646258_s1, Ba04646257_s1, , Ba04646234_s1 for Lactobacillus spp. and Ba04646236_s1, Ba04646278_s1, Ba04646229_s1, Ba04646230_s1, Ba04646222_s1 for BV-associated species). For $L$. vaginalis (KF875988.1) and L. mucoasae (NR_024994.1) Thermo Fisher Scientific designed custom probes based on the referenced nucleotide sequence. The TaqMan probe sequences for L. acidophilus and L. rhamnosus (Haarman and Knol, 2006), as well as B. bifidum and B. longum (Haarman and Knol, 2005) were previously published. Using an ABI 7500 Real-Time PCR Detection System (Thermo Fisher Scientific Inc., USA) we quantified each of the targets. The quantification was performed using amplicons generated from plasmids for each of the targets (TaqMan $^{\mathrm{TM}}$ Vaginal Microbiota Extraction Control). Serial dilutions, ranging from $10^{0}$ to $10^{9}$ molecules per 
$\mu 1$ of sample were used to generate standard curves. Bacterial concentrations were normalized to $16 \mathrm{~S}$ rRNA gene concentrations, as recommended by the manufacturer.

Measurement of IL-1 $\alpha$ concentrations: Samples were thawed on ice and filtered by centrifuging at $1950 \mathrm{~g}$ for 10 minutes at $4^{\circ} \mathrm{C}$ in SPIN-X ${ }^{\circledR} 0.2 \mu \mathrm{M}$ cellulose acetate filters to exclude mucus and debris prior to performing the ELISA. Human IL-1 $\alpha$ concentrations were measured using a commercial ELISA (E-EL-H008, Elabscience ${ }^{\circledR}$, USA), according to the manufacturer's instructions. IL-1 $\alpha$ concentrations were calculated based on the standard curve, using standards provided with the kit. The detection range was $1.25-125 \mathrm{pg} / \mathrm{mL}$, and all values below the detection limit were recorded as half of the lowest concentration measured.

Statistical analyses: As this was a pilot trial intended to test the regulatory environment in South Africa for conducting a trial assessing probiotics, it was not powered for efficacy (defined as BV cure). None-the-less, GraphPad Prism6® (GraphPad Software, USA), STATA version 11.0 (StataCorp, USA) and R were used for statistical analyses and to generate graphs. Mann-Whitney $U$ tests were used to compare groups of continuous variables and two-sided Fisher's exact tests were used for categorical variables. $95 \%$ confidence intervals and $p$-values $\leq 0.05$ were considered significant. 
medRxiv preprint doi: https://doi.org/10.1101/2020.05.04.20090282; this version posted May 8,2020 . The copyright holder for this preprint (which was not certified by peer review) is the author/funder, who has granted medRxiv a license to display the preprint in perpetuity.

\section{Results}

\section{SAHPRA approval}

This trial intended to explore the regulatory environment in South Africa governing probiotic trials, in order to lay the foundation for future trials of novel probiotic products under development. SAHPRA did not require a full application but rather a notification, as the probiotic product was not currently considered/regulated as a medicine but as a health supplement, and available OTC in South Africa.

\section{Cohort behavioural and biomedical characteristics}

A total of 96 women seeking care for vaginal discharge were screened for eligibility (Figure 1), of which the majority ( $\mathrm{n}=90)$ were recruited via the UCT Student Wellness Centre. One woman tested HIV positive at screening, and thus was excluded and referred for care. Of those screened, 43 women (45.3\%) were confirmed to have BV by Nugent Scoring (Nugent 7-10; Table 1), confirming that symptomatic vaginal discharge is a very imprecise tool for predicting the presence of $\mathrm{BV}$ (11), with a positive predictive value of only $45.3 \%$ in this cohort. In addition, $17.9 \%(17 / 95)$ had an STI, with $T$. vaginalis in $9.5 \%$ (9/95) and C. trachomatis in 8.4\% (8/95) being the most common STIs detected. Of the $43 \mathrm{BV}$ positive women, 33/43 were eligible for randomization (BV+ but STI-).

Table 1. Laboratory-diagnosed BV and STIs at screening

\begin{tabular}{|c|c|}
\hline \multicolumn{2}{|l|}{ Characteristic } \\
\hline Age participant [years, median (IQR)] & $22(20-25)$ \\
\hline \multicolumn{2}{|l|}{ Self-identified race $[\%(\mathrm{n} / \mathrm{N})]$} \\
\hline Black & $67.7(65 / 96)$ \\
\hline Coloured & $19.8(19 / 96)$ \\
\hline White & $12.5(12 / 96)$ \\
\hline \multicolumn{2}{|l|}{ Bacterial vaginosis $[\%(\mathrm{n} / \mathrm{N})]^{\mathrm{a}}$} \\
\hline Positive (Nugent Score 7-10) & $45.3(43 / 95)$ \\
\hline Intermediate (Nugent Score 4-6) & $15.8(15 / 95)$ \\
\hline \multicolumn{2}{|c|}{ Bacterial and protozoal infections $[\%(\mathrm{n} / \mathrm{N})]^{\mathrm{a}}$} \\
\hline T. vaginalis & $9.5(9 / 95)$ \\
\hline C. trachomatis & $8.4(8 / 95)$ \\
\hline M. genitalium & $3.2(3 / 95)$ \\
\hline N. gonorrhoea & $2.1(2 / 95)$ \\
\hline \multicolumn{2}{|l|}{ Multiple conditions $[\%(n / N)]^{a}$} \\
\hline BV+/STI- & $34.7(33 / 95)$ \\
\hline BV-/STI+ & $7.4(7 / 95)$ \\
\hline $\mathrm{BV}+/ \mathrm{STI}+$ & $10.5(10 / 95)$ \\
\hline BV-/STI- & $47.4(45 / 95)$ \\
\hline Multiple STIs & $4.2(4 / 95)$ \\
\hline
\end{tabular}

ane participant tested HIV positive, thus screening was aborted. 
medRxiv preprint doi: https://doi.org/10.1101/2020.05.04.20090282; this version posted May 8, 2020. The copyright holder for this preprint (which was not certified by peer review) is the author/funder, who has granted medRxiv a license to display the preprint in perpetuity. All rights reserved. No reuse allowed without permission.

Of the 33 women who were eligible, three were no longer interested in participating, 12 were randomized to the SOC arm (vaginal MetroGel ${ }^{\mathrm{TM}}$ alone; 5 days), while 18 were randomized to the intervention arm (vaginal MetroGel ${ }^{\mathrm{TM}} 5$ days, followed by 15 days of Vagiforte ${ }^{\circledR}$ ). Randomised women were a median age of 22 years (IQR 20-26 years) old, predominantly single $(26 / 30,86.7 \%)$, and self-identified as black $(20 / 30,66.7 \%)$. About one-third reported being previously pregnant (8/30), and one-third reported currently using hormonal contraception (11/30; Table 2). Their median age at sexual debut was reported to be 17 years (IQR 16-19) with a median of five lifetime sexual partners (IQR 3-8). Reporting of oral sex was common (21/30, 70.0\%), while reporting of anal sex was less common $(2 / 30,6.7 \%)$. About half reported regular condom use, and very few $(\mathrm{n}=4)$ reported previously being diagnosed or treated for an STI (Table 2). Almost half reported that they were currently smoking, a factor that has previously been associated with the risk of BV (25-27). Almost all enrolled women (28/30; 93.3\%) reported a history of chronic vaginal discharge. About a third reported using their fingers and water to clean their vaginas internally, while other vaginal practices (such as cleansing with cloth or using traditional South African herbs) were reported less commonly. A third of women reported believing that using vaginal products (either commercial and traditional) to treat their vaginal discharge was beneficial for their vaginal health, and an equal proportion reported concerns that these vaginal products were causing their vaginal discharge and malodour (Table 2). More than half reported previous use of prescription medicine to reduce vaginal discharge and malodour, supporting the history of long-standing vaginal discharge and/or infections in these women. More than half used tampons while menstruating, suggesting that they may be likely to be comfortable with the vaginal application of the probiotic (Table 2). None of these characteristics evaluated differed by study arm.

Table 2. Cohort characteristics at enrolment

\begin{tabular}{|c|c|c|c|}
\hline Characteristic & $\begin{array}{c}\text { All } \\
\mathbf{n}=\mathbf{3 0}\end{array}$ & $\begin{array}{l}\text { SOC } \\
\mathrm{n}=12 \\
\end{array}$ & $\begin{array}{c}\text { Intervention } \\
\mathbf{n}=\mathbf{1 8}\end{array}$ \\
\hline Age participant [years, median (IQR)] & $22(20-26)$ & $23(21-34)$ & $22(20-26)$ \\
\hline \multicolumn{4}{|l|}{ Self-identified race $[\%(n)]$} \\
\hline Black & $66.7(20)$ & $58.3(7)$ & $72.2(13)$ \\
\hline Coloured & $20.0(6)$ & $25.0(3)$ & $16.7(3)$ \\
\hline White & $13.3(4)$ & $16.7(2)$ & $11.1(2)$ \\
\hline Age menarche [years, median (IQR)] & $14(12-15)$ & $12(11-15)$ & $14(13-16)$ \\
\hline \multicolumn{4}{|l|}{ Marital Status [\% (n)] } \\
\hline Single & $86.7(26)$ & $83.3(10)$ & $88.9(16 / 18)$ \\
\hline
\end{tabular}


medRxiv preprint doi: https://doi.org/10.1101/2020.05.04.20090282; this version posted May 8, 2020. The copyright holder for this preprint (which was not certified by peer review) is the author/funder, who has granted medRxiv a license to display the preprint in perpetuity.

\begin{tabular}{|c|c|c|c|}
\hline Married & $3.3(1)$ & $8.3(1)$ & - \\
\hline Separated/Divorced & $10.0(3)$ & $8.3(1)$ & $11.1(2)$ \\
\hline \multicolumn{4}{|l|}{ Pregnancies and contraception $[\%(n / N)]$} \\
\hline Ever been pregnant & $26.7(8)$ & $25.0(3)$ & $27.8(5)$ \\
\hline Currently using hormonal contraception & $36.7(11)$ & $33.3(4)$ & $38.9(7)$ \\
\hline Reported current smoking [\% (n/N)] & $46.7(14)$ & $50.0(6)$ & $44.4(8)$ \\
\hline \multicolumn{4}{|l|}{ Sexual risk behaviour } \\
\hline Age of sexual debut [median (IQR)] & $17(16-19)$ & $18(17-18)$ & $17(16-19)$ \\
\hline Number of lifetime partners [median (IQR)] & $5(3-8)$ & $5(3-8)$ & $4(3-8)$ \\
\hline Number sex partners during last 6 months [median (IQR)] & $1(1-2)$ & $1(1-2)$ & $1(1-2)$ \\
\hline Anal sex during last 6 months $[\%(\mathrm{n} / \mathrm{N})]$ & $6.7(2)$ & - & $11.1(2)$ \\
\hline Oral sex during last 6 months $[\%(\mathrm{n} / \mathrm{N})]$ & $70.0(21)$ & $58.3(7)$ & $77.8(14)$ \\
\hline \multicolumn{4}{|l|}{ Reported condom use $[\%(n / N)]$} \\
\hline Always & $26.7(8)$ & $33.3(4)$ & $22.2(4)$ \\
\hline Most of the time & $36.7(11)$ & $33.3(4)$ & $38.9(7)$ \\
\hline Occasionally & $6.7(2)$ & - & $11.1(2)$ \\
\hline Never & $20.0(6)$ & $25.0(3)$ & $16.7(3)$ \\
\hline Regular condom use during last 6 months & $60.0(18)$ & $66.7(8)$ & $55.6(10)$ \\
\hline Condom use at last sexual act & $53.3(16)$ & $66.7(8)$ & $44.4(8)$ \\
\hline \multicolumn{4}{|l|}{ History of STIs } \\
\hline Ever been diagnosed or treated for a STI $[\%(n / N)]$ & $13.3(4)$ & $8.3(1)$ & $16.7(3)$ \\
\hline Partner or participant STI in last 6 month $[\%(\mathrm{n} / \mathrm{N})]$ & $10.0(3)$ & - & $16.7(3)$ \\
\hline Long-term history of vaginal discharge & $93.3(28)$ & $83.3(10)$ & $100(18)$ \\
\hline \multicolumn{4}{|l|}{ Vaginal product use [\%(n/N)] } \\
\hline Use of medicine from doctor/nurse & $66.7(20)$ & $58.3(7)$ & $72.2(13)$ \\
\hline Use of tampon & $20.0(6)$ & $25.0(3)$ & $16.7(3)$ \\
\hline Cleansing with fingers & $13.3(4)$ & $16.7(2)$ & $11.1(2)$ \\
\hline Sex during period & $33.3(10)$ & $33.3(4)$ & $33.3(6)$ \\
\hline Cleansing with water & $30.0(9)$ & $25.0(3)$ & $33.3(6)$ \\
\hline Douching to clean vagina & $10.0(3)$ & - & $16.7(3)$ \\
\hline Cleansing with soap & $6.7(2)$ & $8.3(1)$ & $5.6(1)$ \\
\hline Cleansing with cloth/sponge & $3.3(1)$ & - & $5.6(1)$ \\
\hline Use of traditional herbs/medicine & $3.3(1)$ & - & $5.6(1)$ \\
\hline Use of drying/tightening agents for sex & $3.3(1)$ & - & $5.6(1)$ \\
\hline Insertion of cloth/paper & - & - & - \\
\hline \multicolumn{4}{|l|}{ Problems after vaginal product use [\% $(\mathrm{n} / \mathrm{N})]$} \\
\hline Yes & $13.3(4)$ & $8.3(1)$ & $16.7(3)$ \\
\hline Itching/irritation & $13.3(4)$ & $8.3(1)$ & $16.7(3)$ \\
\hline Discomfort & $3.3(1)$ & $8.3(1)$ & - \\
\hline Vaginal Infections & $3.3(1)$ & $8.3(1)$ & - \\
\hline \multicolumn{4}{|l|}{ Opinions about vaginal product use [\% (n/N)] } \\
\hline Good for me & $26.7(8)$ & $25.0(3)$ & $27.8(5 / 18)$ \\
\hline Cause discharge and/or smell & $36.7(11)$ & $33.3(4)$ & $38.9(7 / 18)$ \\
\hline Increases chances of getting STIs & $46.7(14)$ & $50.0(6)$ & $44.4(8 / 18)$ \\
\hline Partner want me to use them & $3.3(1)$ & $8.3(1)$ & - \\
\hline Increases chances of getting STIs/HIV & $6.7(2)$ & - & $11.1(2 / 18)$ \\
\hline
\end{tabular}

\section{Adherence to and safety of MetroGel ${ }^{T M}$ and the oral/vaginal probiotic}

Women attended a total of 143 visits, with 25/30 women completing all visits (Figure 1). All women $(n=30)$ reported completing the entire five-day course of MetroGel ${ }^{\mathrm{TM}}$. Similarly, all women randomised to the intervention group $(n=18)$ reported completing the course of oral probiotic capsules, and the majority $(n=16)$ also reported completing the vaginal probiotic spray. Overall, a total of 110 adverse events (AEs) occurred over 
medRxiv preprint doi: https://doi.org/10.1101/2020.05.04.20090282; this version posted May 8, 2020. The copyright holder for this preprint (which was not certified by peer review) is the author/funder, who has granted medRxiv a license to display the preprint in perpetuity.

the course of the trial, of which most $(76.4 \% ; 84 / 110)$ were considered not to be related to study products. Most AEs were mild (grade 1-2, 109/110, 99.1\%) and only one nonrelated AE was grade 3. Unrelated AEs included: headaches (20 periods of headache reported by 5 women), flu-like symptoms ( $\mathrm{n}=18$, reported by 12 women), acquisition of any STI [including C. trachomatis $(\mathrm{n}=8), T$. vaginalis $(\mathrm{n}=7), M$. genitalium $(\mathrm{n}=5)$ and $N$. gonorrhoea $(\mathrm{n}=1)]$, menstrual pain $(\mathrm{n}=7)$, gastro-intestinal complaints $(\mathrm{n}=5)$, temporary vaginal discomfort related to vaginal intercourse $(n=7)$, anaemia $(n=2)$ and cat allergy $(n=1)$, buttock pain $(n=1)$, and anxiety $(n=1)$. More than half of the women $(53.3 \% ; 16 / 30)$ acquired an STI over the course of the study.

Of those AEs that were considered to be related to the use of the study products $(n=26)$, the majority was associated with vaginal $\mathrm{MetroGel}^{\mathrm{TM}}$ use and reported by women who were randomised to the SOC arm $(80.8 \% ; 21 / 26)$. Overall, more than half of the participants $(17 / 30 ; 56.7 \%)$ reported experiencing genital AEs, including vaginal itching/irritation $(9 / 30 ; 30.0 \%)$, candida infections $(5 / 30 ; 16.7 \%)$, discomfort $(3 / 30$; $10.0 \%)$, increased discharge $(2 / 30 ; 6.7 \%)$, spotting $(1 / 30 ; 3.3 \%)$, or constipation after MetroGel ${ }^{\mathrm{TM}}$ use $(1 / 30 ; 3.3 \%)$. Vaginal candida infection and constipation are published side effects of $\mathrm{MetroGel}^{\mathrm{TM}}$, and vaginal itching, discomfort and discharge are likely to be symptoms of candidiasis (28). One third of women $(5 / 18 ; 27.8 \%)$ reported AEs which may have been associated with probiotic use, including vaginal itching/discomfort $(2 / 18 ; 11.1 \%)$, increased vaginal discharge $(1 / 18 ; 5.6 \%)$, increased nipple sensitivity $(1 / 18 ; 5.6 \%)$, and nausea $(1 / 18 ; 5.6 \%)$. Overall, the adherence to both products was high and generally associated with a good safety profile.

\section{Acceptability of the oral-vaginal combination probiotic in South African women}

At the final visit, women in the intervention arm were asked by the research nurse to complete a questionnaire to evaluate the acceptability of the probiotic product used during the trial. The majority of women $(9 / 15,60.0 \%)$ reported that they liked using the combination probiotic, because it was easy to use or resulted in improved vaginal symptoms (Figure 2A). Most women (12/15, 80.0\%) reported that they preferred the oral capsule over the vaginal spray application (Figure 2B), as the spray was difficult to use, "messy and smelly" or AEs occurred. Despite seven women reporting that they did not like using the oral/vaginal probiotic, the vast majority $(14 / 15,93.3 \%)$ believed that they received some benefit from this product and would buy it to use it again, 
medRxiv preprint doi: https://doi.org/10.1101/2020.05.04.20090282; this version posted May 8, 2020. The copyright holder for this preprint (which was not certified by peer review) is the author/funder, who has granted medRxiv a license to display the preprint in perpetuity.

primarily to prevent rather than to treat BV (Figure 2C). The majority $(13 / 15,86.7 \%)$ also said they would recommend it to other women. In terms of future product design, women reported that they would prefer a probiotic with oral application only rather than a combination of oral and vaginal or vaginal only administration (Figure 2D). If vaginal administration was required, women responded that they would prefer a tablet or gel rather than a tampon, spray or capsule. Women reported that they would much prefer to buy the probiotic at pharmacies $(12 / 15,80.0 \%)$ than health stores, a grocery store or clinic (Figure 2E). When questioned about where they prefer to seek advice regarding using probiotics for vaginal health, women responded that they would ask reproductive health nurses $(13 / 15,86.6 \%)$ and doctors $(11 / 15 ; 73.3 \%)$ rather than pharmacists or get information from the internet (Figure $2 \mathrm{~F}$ ). When asked about how much they were willing to spend on such a product, none of the women responded that they would be willing to spend more than 200 South African rand (ZAR), which was less than the cost of the probiotic tested in this trial (costing ZAR 280 per treatment course).

\section{Comparing BV cure rates in SOC and intervention arms}

Although our trial was not powered for efficacy, we were interested in an exploratory intention-to-treat (ITT) analysis to estimate possible benefits of administration of this locally sourced probiotic on BV cure and recurrence (Figure 3A). The overall BV cure rate (defined as achieving a Nugent score 0-3) was 44.8\% (13/29) at month 1 (primary outcome), 46.4\% (13/28) at month 3 and 53.8\% (14/26) at month 5. At month 1, BV cure rates tended to be higher in the SOC arm $(63.6 \% ; 7 / 11)$ than the intervention arm $(33.3 \% ; 6 / 18 ; p=0.113)$. However, almost half of the BV negative women in the SOC arm (3/7) subsequently re-tested BV positive (Nugent 7-10) at month 3, while more than half of the women in the intervention arm who were cured at month $1(4 / 6)$ remained BV negative until the end of the trial. Vagiforte ${ }^{\circledR}$ PLUS did not appear to offer short-term benefits for BV cure compared to MetroGel ${ }^{\mathrm{TM}}$ alone, although it needs to be emphasised that this trial was not adequately powered.

\section{Comparing vaginal $\mathrm{pH}$ in SOC versus intervention arms}

A $\mathrm{pH}>4.5$ is one of the clinical criteria considered in diagnosing BV using Amsel's Criteria (29) and a low vaginal $\mathrm{pH}$ is considered to be beneficial for vaginal health (Aroutcheva et al., 2001; Boskey et al., 1999). Thus, having a vaginal $\mathrm{pH}<4.5$ after BV 
medRxiv preprint doi: https://doi.org/10.1101/2020.05.04.20090282; this version posted May 8, 2020. The copyright holder for this preprint (which was not certified by peer review) is the author/funder, who has granted medRxiv a license to display the preprint in perpetuity. All rights reserved. No reuse allowed without permission.

treatment was considered as a secondary endpoint for this study. In the SOC arm, 6/11 (54.5\%) women had a vaginal $\mathrm{pH}<4.5$ one month after treatment, compared to $11 / 18$ $(61.1 \%)$ in the intervention group $(p=0.514$; Figure 3B). Similarly, no significant difference between the SOC and intervention arms were noted at later time points. Nugent scores correlated significantly with vaginal $\mathrm{pH}$ (Spearman rho $=0.71$; $\mathrm{p}=0.0001)$.

\section{Comparing clinical symptoms in SOC versus intervention arms}

The majority of women (24/29) reported an improvement of their vaginal symptoms one month after treatment, with similar rates in the SOC and intervention arms (Table $3)$. Of these, the majority (20/24) reported a decrease of vaginal discharge, and more than half reported a change in smell and/or colour of the discharge, independently of treatment arm. Similar improvements in vaginal symptoms were reported three months after treatment completion (Table 3).

Table 3. Reported vaginal symptoms one and three months after treatment completion

\begin{tabular}{c|c|c|c|l}
\hline Month 1 [\% (n/N)] & $\begin{array}{c}\text { Overall } \\
\mathbf{n = 2 9}\end{array}$ & $\begin{array}{c}\text { SOC } \\
\mathbf{n = 1 1}\end{array}$ & $\begin{array}{c}\text { Intervention } \\
\mathbf{n = 1 8}\end{array}$ & p-value $^{\mathbf{a}}$ \\
\hline Improvement of discharge & $82.8(24 / 29)$ & $83.3(10 / 11)$ & $77.8(14 / 18)$ & 0.356 \\
\hline Less discharge & $83.3(20 / 24)$ & $90.0(9 / 10)$ & $78.6(11 / 14)$ & 0.437 \\
\hline Change in colour & $54.2(13 / 24)$ & $50.0(5 / 10)$ & $57.1(8 / 14)$ & 0.527 \\
\hline Change in smell & $70.8(17 / 24)$ & $70.0(7 / 10)$ & $71.4(10 / 14)$ & 0.643 \\
\hline Month 3 [\% (n/N)] & $\mathbf{n = 2 8}$ & $\mathbf{n = 1 2}$ & $\mathbf{n = 1 6}$ & \\
\hline Improvement of discharge & $82.1(23 / 28)$ & $83.3(10 / 12)$ & $81.3(13 / 16)$ & 0.643 \\
\hline Less discharge & $73.9(17 / 23)$ & $90.0(9 / 10)$ & $61.5(8 / 13)$ & 0.145 \\
\hline Change in colour & $56.5(13 / 23)$ & $70.0(7 / 10)$ & $46.2(6 / 13)$ & 0.237 \\
\hline Change in smell & $69.6(16 / 23)$ & $80.0(8 / 10)$ & $61.5(8 / 13)$ & 0.313 \\
\hline
\end{tabular}

acFisher's exact test was used for the assessment of proportions between groups.

\section{Testing for the presence of probiotic species in the genital tract}

To estimate whether the bacterial species contained in the oral/vaginal probiotic colonised the FGTs of women in the intervention arm, concentrations of L. rhamnosus, L. acidophilus, B. bifidum and B. longum were measured before and after treatment (Figure 4A). Although not typically considered a vaginal Lactobacillus species, it was interesting to note that a third (20/30) of women had detectable concentrations of $L$. acidophilus (median concentration; $6.24 \times 10^{-8} \mathrm{ng} / \mathrm{mL}$ ) at baseline, although few women had L. rhamnosus (2/30), B. bifidum (2/30) and B. longum (8/30). Despite daily administration of $>2 \times 10^{9} \mathrm{CFU}$ vaginally and orally for a total of 15 days in the intervention group, we observed no clear evidence of colonization of any of the 
medRxiv preprint doi: https://doi.org/10.1101/2020.05.04.20090282; this version posted May 8, 2020. The copyright holder for this preprint

(which was not certified by peer review) is the author/funder, who has granted medRxiv a license to display the preprint in perpetuity.

All rights reserved. No reuse allowed without permission.

bacterial species contained in the probiotic formulation after administration of the probiotic (month 1) or at later time points (Figure 4A).

\section{Changes in commensal Lactobacillus communities following BV treatment}

Lactobacillus spp.-dominated vaginal microbiota are associated with a lack of genital inflammation compared to non-optimal vaginal microbiota (32). However, while some Lactobacillus spp., such as L. crispatus, L. gasseri, L. jensenii and L. vaginalis, have been associated with decreased genital inflammation and HIV risk, the role of others, such as L. iners, remains unclear $(32,33)$. Therefore, we evaluated concentrations of several of these Lactobacillus spp. to assess the beneficial effect of the oral/vaginal probiotic on the vaginal microbiota. Most women had either concentrations below the detection limit or very low concentrations of L. crispatus, L. gasseri, L. jensenii and $L$. vaginalis (all with median concentration $0 \mathrm{ng} / \mathrm{mL}$ ) before treatment (Figure 4B). While some women showed increased concentrations of beneficial vaginal Lactobacillus spp. one month after treatment, others did not, and this did not differ by study arm (Additional Table 1). The relative concentrations of L. mucosae (median concentration $4.03 \times 10^{-2} \mathrm{ng} / \mathrm{mL}$ ) and L. iners (median concentration $5.23 \times 10^{-2} \mathrm{ng} / \mathrm{mL}$ ) were generally higher than the concentrations of the other Lactobacillus spp. and remained higher over the course of the study (Figure 4B).

\section{Changes in BV-associated bacterial communities following BV treatment}

Most women had detectable concentrations of $G$. vaginalis (26/30; median concentration $\left.1.25 \times 10^{-2} \mathrm{ng} / \mathrm{mL}\right)$, P. bivia (21/30; median concentration $7.82 \times 10^{-3}$ $\mathrm{ng} / \mathrm{mL})$ and $A$. vaginae $\left(29 / 30\right.$; median concentration $\left.1.22 \times 10^{-5} \mathrm{ng} / \mathrm{mL}\right)$ pre-treatment (Figure 4C), consistent with their BV status. The concentrations of these BV-associated bacteria remained high throughout the trial despite BV treatment, both in the SOC and intervention arm (Additional Table 1). While most women also had BVAB2 (22/30; $3.31 \times 10^{-5}$ and some Megasphera (14/30) present pre-treatment, some women experienced a loss or decreased quantities of these bacterial species post-treatment, but this was again irrespective of study arm (Figure 4C).

\section{Changes in genital cytokine concentrations following treatment}

IL-1 $\alpha$ concentrations were measured in vaginal samples collected pre- and posttreatment to investigate whether probiotics influenced genital inflammatory cytokine 
medRxiv preprint doi: https://doi.org/10.1101/2020.05.04.20090282; this version posted May 8, 2020. The copyright holder for this preprint (which was not certified by peer review) is the author/funder, who has granted medRxiv a license to display the preprint in perpetuity.

All rights reserved. No reuse allowed without permission.

concentrations compared to SOC. Overall, we found that genital IL-1 $\alpha$ concentrations decreased after treatment (from a median concentration of $4.80 \mathrm{pg} / \mathrm{mL}$ to $1.28 \mathrm{pg} / \mathrm{mL}$ in SOC participants vs. from $11.26 \mathrm{pg} / \mathrm{mL}$ to $10.42 \mathrm{pg} / \mathrm{mL}$ in the intervention group; Figure 5; Additional Table 1), although not significantly. In addition, adjusting for STIs that were acquired during the trial had no impact on this observation. 
medRxiv preprint doi: https://doi.org/10.1101/2020.05.04.20090282; this version posted May 8, 2020. The copyright holder for this preprint (which was not certified by peer review) is the author/funder, who has granted medRxiv a license to display the preprint in perpetuity.

\section{Discussion}

We aimed to explore the regulatory environment in South Africa by conducting a clinical trial with a commercially available OTC probiotic, and thereby to lay the groundwork for assessing the effect of adjunctive probiotics on BV treatment in South Africa. The regulatory environment in South Africa continues to consider OTC probiotics as health supplements, and SAHPRA formally approved this trial. We found that the use of a vaginal/oral probiotic combination was well accepted among South African women and associated with few AEs. Despite general acceptance of the product, we found that this particular oral/vaginal probiotic did not significantly improve BV cure rates following antibiotic treatment of symptomatic BV, neither did it lower vaginal $\mathrm{pH}$ or improve $\mathrm{BV}$ recurrence within five months post-treatment compared to MetroGel $^{\mathrm{TM}}$ alone (SOC), although it needs to be emphasises that our sample was not powered to detect anything other than large changes. This result, while disappointing, also calls for stricter regulations of probiotics in South Africa. The World Health Organization defines probiotics as "live microorganisms which when administered in adequate amounts confer a health benefit on the host", thus in order to be labelled a probiotic, scientific evidence demonstrating a health benefit needs to be well documented. Products that contain bacterial strains with no proven health benefit should not be labelled probiotics and marketed as such, as these strains, strictly spoken, cannot be considered probiotics as the health benefit is included in the definition of a probiotic. Marketing "probiotics" with no proven health benefit may lead to misleading perceptions and generalised criticism of all probiotics, although some do have a proven health benefit.

While we were not able to detect a beneficial effect of adjunctive Vagiforte ${ }^{\circledR}$ PLUS Combo Pack under these trial conditions, possibly due to the small sample size, the product was found to be generally safe. Women reportedly preferred the oral over the vaginal application of the probiotic, as the administration of the vaginal spray (in its reusable spray applicator) was uncomfortable and messy. Thus, for future probiotic product design, women's preferences should be taken into consideration and probiotics containing well-selected vaginal Lactobacillus spp. should be administered orally or topically as vaginal tablet or gel. Importantly, women were not willing to spend more than ZAR 200 for one treatment course. Considering the current prices for probiotics 
medRxiv preprint doi: https://doi.org/10.1101/2020.05.04.20090282; this version posted May 8, 2020. The copyright holder for this preprint (which was not certified by peer review) is the author/funder, who has granted medRxiv a license to display the preprint in perpetuity.

on the South African market (22), this emphasizes the need for affordable treatment options for those most in need of it.

Ideally, the vaginal microbiota should be dominated by beneficial Lactobacillus spp. (32), thereby contributing to the effectiveness of the host mucosal barrier against infection. The selected OTC oral/vaginal probiotic, like all those available in South Africa, did not contain Lactobacillus spp. that are commonly associated with vaginal health, internationally and in South African women (19). It was therefore not unexpected that both the proportion of women and the relative concentrations of Vagiforte ${ }^{\circledR}$ bacterial species were found to be similar in women in the intervention and SOC arm, and evidence of probiotic colonization was lacking. This suggests that the probiotic strains did not effectively colonize the FGTs of women randomised to the intervention arm, despite having proven viability at the initiation of the trial. This may be due to the fact that Vagiforte ${ }^{\circledR}$ PLUS did not contain vaginal Lactobacillus spp. commonly associated with reproductive health (such as L. crispatus, L. gasseri, L. jensenii or L. vaginalis) and thus likely did not effectively colonise the FGT. Similarly, others have reported that supplementation of standard antibiotic therapy with commercially-available probiotic lactobacilli in South African women with BV does not confer a measurable benefit (18), indicating that better designed probiotic products for treating BV need to be developed and made available for South African women. These products should contain well characterised vaginal Lactobacillus strains with confirmed beneficial probiotic characteristics that have ideally been isolated from the FGTs of healthy South African women.

Some additional recommendations for the design of future probiotic trials in South Africa can be made from this study. Clinical studies should test for BV cure shortly after treatment completion to minimize the likelihood that women have a recurrent BV event, in order to differentiate BV cure rates from confounding repeat episodes. Further, this trial was a superiority trial rather than placebo-controlled, as we tested the intervention against MetroGel ${ }^{\mathrm{TM}}$ instead of placebo or oral metronidazole as control group (34), which is likely to have made it harder to detect differences. Further, oral metronidazole is in fact more commonly used in South Africa for treating BV due to its lower cost compared to MetroGel ${ }^{\mathrm{TM}}$, which is slightly more effective and has less systemic side effects than the cheaper oral formulation $(35,36)$. 
medRxiv preprint doi: https://doi.org/10.1101/2020.05.04.20090282; this version posted May 8,2020 . The copyright holder for this preprint

(which was not certified by peer review) is the author/funder, who has granted medRxiv a license to display the preprint in perpetuity.

All rights reserved. No reuse allowed without permission.

The limitations of this study include the small number of participants, however this was a pilot intended to test the regulatory environment. Further, administration of the study drugs was self-reported and vaginal $\mathrm{pH}$ was not being measured pre-treatment. Further, no $16 \mathrm{~S}$ rRNA gene sequencing to evaluate relative vaginal bacterial abundance was performed. However, detailed information on vaginal practices, behavioural and sexual risk factors, study product use, side effects, and concomitant medications were collected which allowed assessment of potential confounders.

\section{Conclusions}

This randomized single-blinded trial provided important regulatory and clinical considerations critical in the design of future clinical trial, with improved probiotic products and larder sample siezes. Although the trial was not powered to determine a beneficial effect of this probiotic on BV cure in South African women over metronidazole treatment alone, it showed that oral and vaginal probiotics were generally safe to use and acceptable in South African BV positive women. Due to the critical need to manage BV better internationally and in South Africa, future regulatory approved, double-blind, randomized, placebo-controlled trial powered for efficacy, using a probiotic product containing beneficial, well-characterised vaginal Lactobacillus strains are needed to conclusively determine the efficacy of adjunctive probiotics on BV cure and recurrence in South African women. In a region with some of the highest rates of BV, STIs and HIV, it is critical that the regulatory environment is established and tested to facilitate the evaluation of these improved products once they enter clinical trials.

\section{List of Abbreviations}

$\mathrm{BV}-$ Bacterial vaginosis

BVAB2 - Bacterial Vaginosis-Associated Bacterium 2

CFU - colony-forming units

CRC - Clinical Research Centre

FGT - female genital tract

ICH - International Conference on Harmonisation

OTC - over-the-counter

$\mathrm{RCT}$ - randomized controlled trial 
medRxiv preprint doi: https://doi.org/10.1101/2020.05.04.20090282; this version posted May 8, 2020. The copyright holder for this preprint (which was not certified by peer review) is the author/funder, who has granted medRxiv a license to display the preprint in perpetuity.

All rights reserved. No reuse allowed without permission.

SA-GCP - South African Good Clinical Practice

SAHPRA - South African Health Products Regulatory Authority

sBHI - Brain Heart Infusion supplemented with $0.1 \%$ starch and $1 \%$ yeast

SOC - Standard of care

STI - sexually transmitted infections

UCT - University of Cape Town

ZAR - South African Rand 
medRxiv preprint doi: https://doi.org/10.1101/2020.05.04.20090282; this version posted May 8,2020 . The copyright holder for this preprint

(which was not certified by peer review) is the author/funder, who has granted medRxiv a license to display the preprint in perpetuity.

\section{Declarations}

Ethics approval and consent to participate: Approval for this clinical trial was obtained from University of Cape Town (UCT) Human Research Ethics Committee (HREC Ref 706/2016) and the South African National Health Research Ethics Council (NHREC Ref 4579). The trial was registered with the South African National Clinical Trial Register of the Department of Health (DOH-27-1117-5579; PI: S. Barnabas) and conducted in full compliance with South African Good Clinical Practice (SA-GCP) and International Conference on Harmonisation (ICH)-GCP, supported by the UCT Clinical Research Centre (CRC). Before undergoing any trial-related procedures, all women provided written informed consent.

Consent for publication: Not applicable.

Availability of data and materials: The datasets used and/or analysed during the current study are available from the corresponding author on reasonable request.

Competing interests: None of the authors reported any conflict of interest. We confirm that none of the manufacturers of Vagiforte PLUS ${ }^{\circledR}$ were involved in the design or testing of this product and did not contribute financially in any way towards the conduct of this study. In addition, we confirm that none of the authors involved in this study are associated in any way financially or otherwise with Bioflora, the manufacturer of Vagiforte PLUS ${ }^{\circledR}$.

Funding: The study was funded by DST-NRF CAPRISA Centre of Excellence in HIV Prevention (PI: J. Passmore). AUH received bursaries from the South African Poliomyelitis Research Foundation and National Research Foundation during her $\mathrm{PhD}$, and Postgraduate Publication Incentive funding from the University of Cape Town. The funders had no role the design of the study and collection, analysis, and interpretation of data and in writing the manuscript.

Authors' Contributions: AUH designed the trial, enrolled the cohort, performed the experiments, analysis and wrote the manuscript. RS and NM performed some of the experiments. HJ and KM contributed to writing the paper. SLB and JSP designed the 
medRxiv preprint doi: https://doi.org/10.1101/2020.05.04.20090282; this version posted May 8, 2020. The copyright holder for this preprint (which was not certified by peer review) is the author/funder, who has granted medRxiv a license to display the preprint in perpetuity.

All rights reserved. No reuse allowed without permission.

trial, enrolled the cohort and contributed to analysis and writing the paper. All authors have read and approved the manuscript.

Acknowledgements: We would like to thank the UCT CRC for their regulatory support and help in setting up and running the trial. 
medRxiv preprint doi: https://doi.org/10.1101/2020.05.04.20090282; this version posted May 8, 2020. The copyright holder for this preprint (which was not certified by peer review) is the author/funder, who has granted medRxiv a license to display the preprint in perpetuity.

\section{References}

1. Kenyon C, Colebunders R, Crucitti T. The global epidemiology of bacterial vaginosis: A systematic review. Am J Obstet Gynecol. 2013;209(6):505-23.

2. Haggerty CL, Totten PA, Tang G, Astete SG, Ferris MJ, Norori J, et al. Identification of novel microbes associated with pelvic inflammatory disease and infertility. Sex Transm Infect. 2016;sextrans-2015-052285.

3. Nelson DB, Hanlon A, Nachamkin I, Haggerty C, Mastrogiannis DS, Liu C, et al. Early pregnancy changes in bacterial vaginosis-associated bacteria and preterm delivery. Paediatr Perinat Epidemiol. 2014;28(2):88-96.

4. Cohen CR, Lingappa JR, Baeten JM, Ngayo MO, Spiegel CA, Hong T, et al. Bacterial vaginosis associated with increased risk of female-to-male HIV-1 transmission: A prospective cohort analysis among african couples. PLoS Med. 2012;9(6):18.

5. Anahtar MN, Byrne EH, Doherty KE, Bowman BA, Yamamoto S, Soumillon M, et al. Inflammatory Responses in the Female Genital Tract. Immunity. 2016;42(5):965-76.

6. Lennard K, Dabee S, Barnabas SL, Havyarimana E, Blakney A, Jaumdally SZ, et al. Microbial composition predicts genital tract inflammation and persistent bacterial vaginosis in South African adolescent females. Infect Immun. $2018 ; 86(1)$.

7. Barrons R, Tassone D. Use of Lactobacillus probiotics for bacterial genitourinary infections in women: A review. Clin Ther. 2008;30(3):453-68.

8. Bradshaw CS, Morton AN, Hocking J, Garland SM, Morris MB, Moss LM, et al. High recurrence rates of bacterial vaginosis over the course of 12 months after oral metronidazole therapy and factors associated with recurrence. J Infect Dis. 2006;193(11):1478-86.

9. Johnson LF, Dorrington RE, Bradshaw D, Coetzee DJ. The effect of syndromic management interventions on the prevalence of sexually transmitted infections in South Africa. Sex Reprod Healthc. 2011;2(1):13-20.

10. Mlisana K, Naicker N, Werner L, Roberts L, Van Loggerenberg F, Baxter C, et al. Symptomatic vaginal discharge is a poor predictor of sexually transmitted infections and genital tract inflammation in high-risk women in South Africa. J Infect Dis. 2012;206(1):6-14.

11. Barnabas SL, Dabee S, Passmore JS, Jaspan HB, Lewis DA, Jaumdally SZ, et 
medRxiv preprint doi: https://doi.org/10.1101/2020.05.04.20090282; this version posted May 8, 2020. The copyright holder for this preprint

al. Converging epidemics of sexually transmitted infections and bacterial vaginosis in southern African female adolescents at risk of HIV. Int J STD AIDS. 2017;0(0):1-9.

12. McKinnon LR, Liebenberg LJ, Yende-Zuma N, Archary D, Ngcapu S, Sivro A, et al. Genital inflammation undermines the effectiveness of tenofovir gel in preventing HIV acquisition in women. Nat Med. 2018;24(4):491-6.

13. Marcone V, Rocca G, Lichtner M, Calzolari E. Long-term vaginal administration of Lactobacillus rhamnosus as a complementary approach to management of bacterial vaginosis. Int J Gynecol Obstet. 2010;110:223-6.

14. Vicariotto F, Mogna L, Del Piano M. Effectiveness of the Two Microorganisms Lactobacillus Formulated in Slow-release Vaginal Tablets , in Women Affected by Bacterial Vaginosis. J Clin Gastroenterol. 2014;48:S10612.

15. Li C, Wang T, Li Y, Zhang T, Wang Q, He J, et al. Probiotics for the treatment of women with bacterial vaginosis: A systematic review and meta-analysis of randomized clinical trials. Eur J Pharmacol. 2019;864(September):172660.

16. Anukam K, Osazuwa E, Ahonkhai I, Ngwu M, Osemene G, Bruce AW, et al. Augmentation of antimicrobial metronidazole therapy of bacterial vaginosis with oral probiotic Lactobacillus rhamnosus GR-1 and Lactobacillus reuteri RC-14: randomized, double-blind, placebo controlled trial. Microbes Infect. 2006;8(6):1450-4.

17. Irvine SL, Hummelen R, Hekmat S, Looman CWN, Habbema JDF, Reid G. Probiotic Yogurt Consumption is Associated With an Increase of CD4 Count Among People Living With HIV / AIDS. J Clin Gastroenterol. 2010;44(9):201-5.

18. Marcotte H, Larsson PG, Andersen KK, Zuo F, Mikkelsen LS, Brandsborg E, et al. An exploratory pilot study evaluating the supplementation of standard antibiotic therapy with probiotic lactobacilli in south African women with bacterial vaginosis. BMC Infect Dis. 2019;19(1):1-15.

19. Lennard K, Dabee S, Barnabas SL, Havyarimana E, Blakney A, Jaumdally SZ, et al. Microbial composition predicts genital inflammation and persistent bacterial vaginosis in adolescent South African women. Infect Immun. 2017;86(1):e00410-17.

20. Noyes N, Cho K, Ravel J, Forney LJ, Abdo Z. Associations between sexual 
medRxiv preprint doi: https://doi.org/10.1101/2020.05.04.20090282; this version posted May 8, 2020. The copyright holder for this preprint

habits , menstrual hygiene practices, demographics and the vaginal microbiome as revealed by Bayesian network analysis. PLoS One. 2018;13(1):e0191625.

21. Anahtar MN, Byrne EH, Fichorova RN, Kwon DS, Anahtar MN, Byrne EH, et al. Cervicovaginal Bacteria Are a Major Modulator of Host Inflammatory Responses in the Female Genital Article Cervicovaginal Bacteria Are a Major Modulator of Host Inflammatory Responses in the Female Genital Tract. Immunity. 2015;42(5):965-76.

22. Happel A-U, Jaumdally SZ, Pidwell T, Cornelius T, Jaspan HB, Froissart R, et al. Probiotics for vaginal health in South Africa : what is on retailers' shelves? BMC Womens Health. 2017;17(7).

23. Haarman M, Knol J. Quantitative Real-Time PCR Analysis of Fecal \&lt;em\&gt;Lactobacillus\&lt;/em\&gt; Species in Infants Receiving a Prebiotic Infant Formula. Appl Environ Microbiol. 2006 Apr 1;72(4):2359 LP - 2365.

24. Haarman M, Knol J. Quantitative Real-Time PCR Assays To Identify and Quantify Fecal \&lt;em\&gt;Bifidobacterium\&lt;/em\&gt; Species in Infants Receiving a Prebiotic Infant Formula. Appl Environ Microbiol. 2005 May 1;71(5):2318 LP - 2324.

25. Hellberg D, Nilsson S, Mardh P-A. Bacterial vaginosis and smoking. Int J STD AIDS. 2000;11:603-6.

26. Brotman RM, He X, Gajer P, Fadrosh D, Sharma E, Mongodin EF, et al. Association between cigarette smoking and the vaginal microbiota : a pilot study. BMC Infect Dis. 2014;14(471).

27. Cherpes TL, Hillier SL, Meyn LA, Busch JL, Krohn MA. A Delicate Balance: Risk Factors for Acquisition of Bacterial Vaginosis Include Sexual Activity, Absence of Hydrogen Peroxide-Producing Lactobacilli, Black Race, and Positive Herpes Simplex Virus Type 2 Serology. Sex Transm Dis. 2008;35(1):78-83.

28. Davis S. Bacterial vaginosis and its treatment with a focus on metronidazole gel. SA Pharm Assist. 2019;19(3):10-2.

29. Amsel R, Totten PA, Spiegel CA, Chen KCS, Eschenbach D, Holmes KK. Nonspecific vaginitis. Diagnostic criteria and microbial and epidemiologic associations. Am J Med. 1983;74(1):14-22.

30. Boskey ER, Telsch KM, Whaley KJ, Moench TR, Cone RA. Acid production 
by vaginal flora in vitro is consistent with the rate and extent of vaginal acidification. Infect Immun. 1999;67(10):5170-5.

31. Aroutcheva A, Gariti D, Simon M, Shott S, Faro J, Simoes JA, et al. Defense factors of vaginal lactobacilli. Am J Obstet Gynecol. 2001;185(2):375-9.

32. McKinnon LR, Achilles SL, Bradshaw CS, Burgener A, Crucitti T, Fredricks DN, et al. The Evolving Facets of Bacterial Vaginosis: Implications for HIV Transmission. AIDS Res Hum Retroviruses. 2019 Mar;35(3):219-28.

33. Gosmann C, Anahtar MN, Handley SA, Farcasanu M, Abu-Ali G, Bowman BA, et al. Lactobacillus-Deficient Cervicovaginal Bacterial Communities Are Associated with Increased HIV Acquisition in Young South African Women. Immunity. 2017/01/10. 2017 Jan 17;46(1):29-37.

34. Goldfarb D. Superiority trials, non-inferiority trials, and prisoners of the 2sided null hypothesis. Evid Based Med. 2004;9(4):100-100.

35. Bistoletti P, Fredricsson B, Hagström B, Nord C-E. Comparison of Oral and Vaginal Metronidazole Therapy for Nonspecific Bacterial Vaginosis. Gynecol Obstet Invest. 1986;21(3):144-9.

36. Koumans EH, Markowitz LE, Hogan V, Group CDCBVW. Indications for Therapy and Treatment Recommendations for Bacterial Vaginosis in Nonpregnant and Pregnant Women: A Synthesis of Data. Clin Infect Dis. 2002 Oct 15;35(Supplement_2):S152-72. 
Additional Table 1. Median vaginal bacterial and IL-1 $\alpha$ concentrations in the SOC and intervention arm

\begin{tabular}{|c|c|c|c|c|c|c|c|c|c|c|c|c|}
\hline \multirow[b]{2}{*}{$\begin{array}{l}\text { Median (IQR) } \\
{[\mathrm{ng} / \mathrm{mL}]}\end{array}$} & \multicolumn{3}{|c|}{ Pre-treatment } & \multicolumn{3}{|c|}{ Month 1} & \multicolumn{3}{|c|}{ Month 3} & \multicolumn{3}{|c|}{ Month 5} \\
\hline & $\begin{array}{c}\text { SOC } \\
n=12\end{array}$ & $\underset{n=18}{\text { Int. }}$ & p-value & $\begin{array}{l}\text { SOC } \\
n=11\end{array}$ & $\underset{n=18}{\text { Int. }}$ & p-value & $\begin{array}{c}\text { SOC } \\
n=11\end{array}$ & 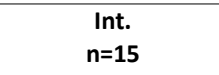 & p-value & $\begin{array}{c}\text { SOC } \\
n=10\end{array}$ & $\underset{n=14}{\text { Int. }}$ & $p$-value \\
\hline L. crispatus & $\begin{array}{c}0 \\
\left(0-2.09 \times 10^{-6}\right)\end{array}$ & $\begin{array}{c}0 \\
(0-0) \\
\end{array}$ & 0.2589 & $\begin{array}{l}2.71 \times 10^{-6} \\
(0-0.001) \\
\end{array}$ & $\begin{array}{c}0 \\
\left(0-1.61 \times 10^{-5}\right)\end{array}$ & 0.0223 & $\begin{array}{c}0 \\
(0-0.003)\end{array}$ & $\begin{array}{c}0 \\
\left(0-5.1 \times 10^{-5}\right)\end{array}$ & 0.3430 & $\begin{array}{c}0 \\
(0-0.0004)\end{array}$ & $\begin{array}{c}0 \\
(0-0.0005)\end{array}$ & 0.2935 \\
\hline L. gasseri & $\begin{array}{c}0 \\
\left(0-1.04 \times 10^{-7}\right)\end{array}$ & $\begin{array}{c}0 \\
0 \\
\left(0-5.88 \times 10^{-8}\right)\end{array}$ & 0.5310 & $\begin{array}{c}0 \\
(0-0)\end{array}$ & $\begin{array}{c}0 \\
(0-0)\end{array}$ & 0.2570 & $\begin{array}{c}0 \\
(0-0)\end{array}$ & $\begin{array}{c}0 \\
\left(0-9.07 \times 10^{-5}\right)\end{array}$ & 0.2957 & $\begin{array}{c}0 \\
\left(0-1.98 \times 10^{-5}\right)\end{array}$ & $\begin{array}{c}0 \\
\left(0-2.02 \times 10^{-6}\right) \\
\end{array}$ & 0.5138 \\
\hline L. jensenii & $\begin{array}{c}0 \\
\left(0-2.71 \times 10^{-7}\right)\end{array}$ & $\begin{array}{c}3.79 \times 10^{-7} \\
(0-0.0004)\end{array}$ & 0.0526 & $\begin{array}{c}0 \\
\left(0-1.23 \times 10^{-5}\right)\end{array}$ & $\begin{array}{l}6.02 \times 10^{-10} \\
(0-0.001)\end{array}$ & 0.1044 & $\begin{array}{l}1.19 \times 10^{-9} \\
(0-0.001)\end{array}$ & $\begin{array}{c}0 \\
\left(0-2.75 \times 10^{-5}\right)\end{array}$ & 0.1149 & $\begin{array}{l}2.65 \times 10^{-5} \\
(0-0.001)\end{array}$ & $\begin{array}{c}0 \\
\left(0-6.21 \times 10^{-5}\right)\end{array}$ & 0.0787 \\
\hline L. vaginalis & $\begin{array}{c}0 \\
\left(0-3.7 \times 10^{-7}\right)\end{array}$ & $\begin{array}{c}0 \\
\left(0-4.45 \times 10^{-6}\right)\end{array}$ & 0.4432 & $\begin{array}{c}0 \\
(0-0.0001)\end{array}$ & $\begin{array}{c}0 \\
\left(0-9.98 \times 10^{-5}\right)\end{array}$ & 0.4243 & $\begin{array}{c}0 \\
(0-0)\end{array}$ & $\begin{array}{c}0 \\
(0-0)\end{array}$ & 0.4712 & $\begin{array}{c}0 \\
(0-001)\end{array}$ & $\begin{array}{c}0 \\
(0-0.001)\end{array}$ & 0.5057 \\
\hline L. mucosae & $\begin{array}{c}0.024 \\
(0.004-0.144) \\
\end{array}$ & $\begin{array}{c}0.041 \\
(0.006-0.302)\end{array}$ & 0.2537 & $\begin{array}{c}0.008 \\
(0.002-0.173)\end{array}$ & $\begin{array}{c}0.009 \\
(0.002-0.020)\end{array}$ & 0.4184 & $\begin{array}{c}0.026 \\
(0.007-0.122)\end{array}$ & $\begin{array}{c}0.023 \\
(0.005-0.196)\end{array}$ & 0.4349 & $\begin{array}{c}0.020 \\
(0.016-0.032)\end{array}$ & $\begin{array}{c}0.024 \\
(0.008-0.255)\end{array}$ & 0.3050 \\
\hline L. iners & $\begin{array}{c}0.025 \\
(0.001-8.345)\end{array}$ & $\begin{array}{c}0.067 \\
(0.01-0.552)\end{array}$ & 0.4668 & $\begin{array}{c}0.024 \\
(0.001-0.172)\end{array}$ & $\begin{array}{c}0.043 \\
(0.007-0.295)\end{array}$ & 0.2227 & $\begin{array}{c}0.044 \\
(0.013-0.175)\end{array}$ & $\begin{array}{c}0.082 \\
(0.026-0.256)\end{array}$ & 0.3101 & $\begin{array}{c}0.057 \\
(0.004-0.456)\end{array}$ & $\begin{array}{c}0.069 \\
(0.001-0344)\end{array}$ & 0.4887 \\
\hline L. acidophilus & $\begin{array}{c}8.79 \times 10^{-8} \\
\left(0-8.89 \times 10^{-6}\right)\end{array}$ & $\begin{array}{c}5.83 \times 10^{-8} \\
\left(0-2.22 \times 10^{-6}\right)\end{array}$ & 0.3867 & $\begin{array}{c}2.00 \times 10^{-8} \\
\left(0-3.56 \times 10^{-5}\right)\end{array}$ & $\begin{array}{c}6.01 \times 10^{-9} \\
\left(0-2.53 \times 10^{-5}\right)\end{array}$ & 0.4897 & $\begin{array}{c}3.37 \times 10^{-8} \\
(0-0.0004)\end{array}$ & $\begin{array}{l}2.23 \times 10^{-7} \\
(0-0.010)\end{array}$ & 0.3918 & $\begin{array}{c}6.86 \times 10^{-7} \\
(0-0.0001)\end{array}$ & $\begin{array}{c}1.85 \times 10^{-7} \\
(0-0.0001)\end{array}$ & 0.4123 \\
\hline L. rhamnosus & $\begin{array}{c}0 \\
(0-0)\end{array}$ & $\begin{array}{c}0 \\
(0-0)\end{array}$ & 0.4000 & $\begin{array}{c}0 \\
(0-0)\end{array}$ & $\begin{array}{c}0 \\
(0-0)\end{array}$ & 0.6207 & $\begin{array}{c}0 \\
(0-0)\end{array}$ & $\begin{array}{c}0 \\
(0-0)\end{array}$ & 0.6769 & $\begin{array}{c}0 \\
(0-0)\end{array}$ & $\begin{array}{c}0 \\
(0-0)\end{array}$ & 0.5833 \\
\hline B. bifidum & $\begin{array}{c}0 \\
(0-0)\end{array}$ & $\begin{array}{c}0 \\
(0-0)\end{array}$ & 0.1517 & $\begin{array}{c}0 \\
0 \\
\left(0-4.40 \times 10^{-9}\right)\end{array}$ & $\begin{array}{c}0 \\
(0-0)\end{array}$ & 0.3799 & $\begin{array}{c}0 \\
(0-0)\end{array}$ & $\begin{array}{c}0 \\
(0-0)\end{array}$ & 0.2587 & $\begin{array}{c}0 \\
(0-6.735)\end{array}$ & $\begin{array}{c}0 \\
0 \\
(0-0)\end{array}$ & 0.1630 \\
\hline B. longum & $\begin{array}{c}0 \\
\left(0-1.19 \times 10^{-6}\right)\end{array}$ & $\begin{array}{c}0 \\
0 \\
(0-0)\end{array}$ & 0.1021 & $\begin{array}{c}0 \\
(0-0)\end{array}$ & $\begin{array}{c}0 \\
\left(0-5.61 \times 10^{-8}\right)\end{array}$ & 0.0578 & $\begin{array}{c}0 \\
\left(0-7.21 \times 10^{-5}\right)\end{array}$ & $\begin{array}{c}0 \\
(0-0)\end{array}$ & 0.2403 & $\begin{array}{c}0 \\
(0-0)\end{array}$ & $\begin{array}{c}0 \\
(0-0)\end{array}$ & 0.5833 \\
\hline G. vaginalis & $\begin{array}{c}0.025 \\
(0.0001-0.358)\end{array}$ & $\begin{array}{c}0.001 \\
\left(7.6 \times 10^{-6}-0.067\right)\end{array}$ & 0.2069 & $\begin{array}{c}0.001 \\
\left(7.75 \times 10^{-6}-0.018\right)\end{array}$ & $\begin{array}{c}0.002 \\
(0-0.017)\end{array}$ & 0.2774 & $\begin{array}{c}0.001 \\
\left(9.38 \times 10^{-5}-0.05\right)\end{array}$ & $\begin{array}{c}0.001 \\
(0-0.156)\end{array}$ & 0.3210 & $\begin{array}{c}0.0003 \\
\left(3.01 \times 10^{-8}-0.006\right)\end{array}$ & $\begin{array}{l}2.91 \times 10^{-5} \\
(0-0.016)\end{array}$ & 0.4577 \\
\hline P. bivia & $\begin{array}{c}2.78 \times 10^{-5} \\
\left(5.11 \times 10^{-7}-0.015\right)\end{array}$ & $\begin{array}{l}4.51 \times 10^{-6} \\
(0-0.0001)\end{array}$ & 0.0969 & $\begin{array}{c}2.99 \times 10^{-6} \\
\left(0-3.15 \times 10^{-5}\right)\end{array}$ & $\begin{array}{l}1.72 \times 10^{-5} \\
(0-0.002)\end{array}$ & 0.3518 & $\begin{array}{c}1.05 \times 10^{-5} \\
\left(3.75 \times 10^{-7}-0.0002\right)\end{array}$ & $\begin{array}{c}1.1 \times 10^{-6} \\
\left(0-1.48 \times 10^{-5}\right)\end{array}$ & 0.1232 & $\begin{array}{c}0 \\
(0-0.002)\end{array}$ & $\begin{array}{c}5.36 \times 10^{-6} \\
\left(0-6.30 \times 10^{-5}\right)\end{array}$ & 0.3847 \\
\hline Atopobium & $\begin{array}{c}0.009 \\
(0.001-0.225) \\
\end{array}$ & $\begin{array}{c}0.008 \\
\left(1.2 \times 10^{-5}-0.1\right)\end{array}$ & 0.4881 & $\begin{array}{c}0.001 \\
\left(3.54 \times 10^{-6}-0.005\right)\end{array}$ & $\begin{array}{c}0.003 \\
\left(1.04 \times 10^{-6}-0.057\right)\end{array}$ & 0.3299 & $\begin{array}{c}0.002 \\
(0-0.014) \\
\end{array}$ & $\begin{array}{c}1.23 \times 10^{-5} \\
\left(3.97 \times 10^{-10}-0.019\right)\end{array}$ & 0.3447 & $\begin{array}{c}0.0001 \\
\left(6.02 \times 10^{-6}-0.003\right)\end{array}$ & $\begin{array}{c}0.0003 \\
(0-0.003)\end{array}$ & 0.4367 \\
\hline BVAB2 & $\begin{array}{c}0.0005 \\
\left(1.54 \times 10^{-7}-0.006\right)\end{array}$ & $\begin{array}{c}4.51 \times 10^{-7} \\
(0-0.0001)\end{array}$ & 0.2739 & $\begin{array}{l}4.68 \times 10^{-5} \\
(0-0.002)\end{array}$ & $\begin{array}{l}9.06 \times 10^{-7} \\
(0-0.002)\end{array}$ & 0.2261 & $\begin{array}{c}6.26 \times 10^{-11} \\
\left(0-3.34 \times 10^{-5}\right)\end{array}$ & $\begin{array}{c}0 \\
\left(0-6.65 \times 10^{-10}\right)\end{array}$ & 0.2590 & $\begin{array}{c}0 \\
\left(0-8.07 \times 10^{-7}\right)\end{array}$ & $\begin{array}{c}0 \\
0 \\
\left(0-1.05 \times 10^{-5}\right)\end{array}$ & 0.4103 \\
\hline Megasphaera & $\begin{array}{l}5.53 \times 10^{-5} \\
(0-0.003)\end{array}$ & $\begin{array}{c}0 \\
\left(0-3.28 \times 10^{-5}\right)\end{array}$ & 0.0922 & $\begin{array}{c}0 \\
(0-0.0002)\end{array}$ & $\begin{array}{c}0 \\
(0-0)\end{array}$ & 0.2036 & $\begin{array}{c}0 \\
(0-0.108)\end{array}$ & $\begin{array}{c}0 \\
(0-0)\end{array}$ & 0.3457 & $\begin{array}{c}0 \\
(0-0.172)\end{array}$ & $\begin{array}{c}0 \\
(0-0)\end{array}$ & 0.2421 \\
\hline $\mathrm{IL}-1 \alpha[\mathrm{pg} / \mathrm{mL}]$ & $\begin{array}{c}4.80 \\
(0.64-37.63)\end{array}$ & $\begin{array}{c}11.26 \\
(0.64-19.16)\end{array}$ & 0.4044 & $\begin{array}{c}1.28 \\
(0.64-35.84)\end{array}$ & $\begin{array}{c}10.42 \\
(0.64-32.18)\end{array}$ & 0.1918 & $\begin{array}{c}4.36 \\
(0.64-12.74)\end{array}$ & $\begin{array}{c}11.96 \\
(2.68-19.33)\end{array}$ & 0.0491 & $\begin{array}{c}6.37 \\
(3.04-33.03)\end{array}$ & $\begin{array}{c}9.57 \\
(0.64-49.65)\end{array}$ & 0.4622 \\
\hline
\end{tabular}

The Mann-Whitney test was used to compare SOC and intervention arms. 
medRxiv preprint doi: https://doi.org/10.1101/2020.05.04.20090282; this version posted May 8, 2020. The copyright holder for this preprint (which was not certified by peer review) is the author/funder, who has granted medRxiv a license to display the preprint in perpetuity.

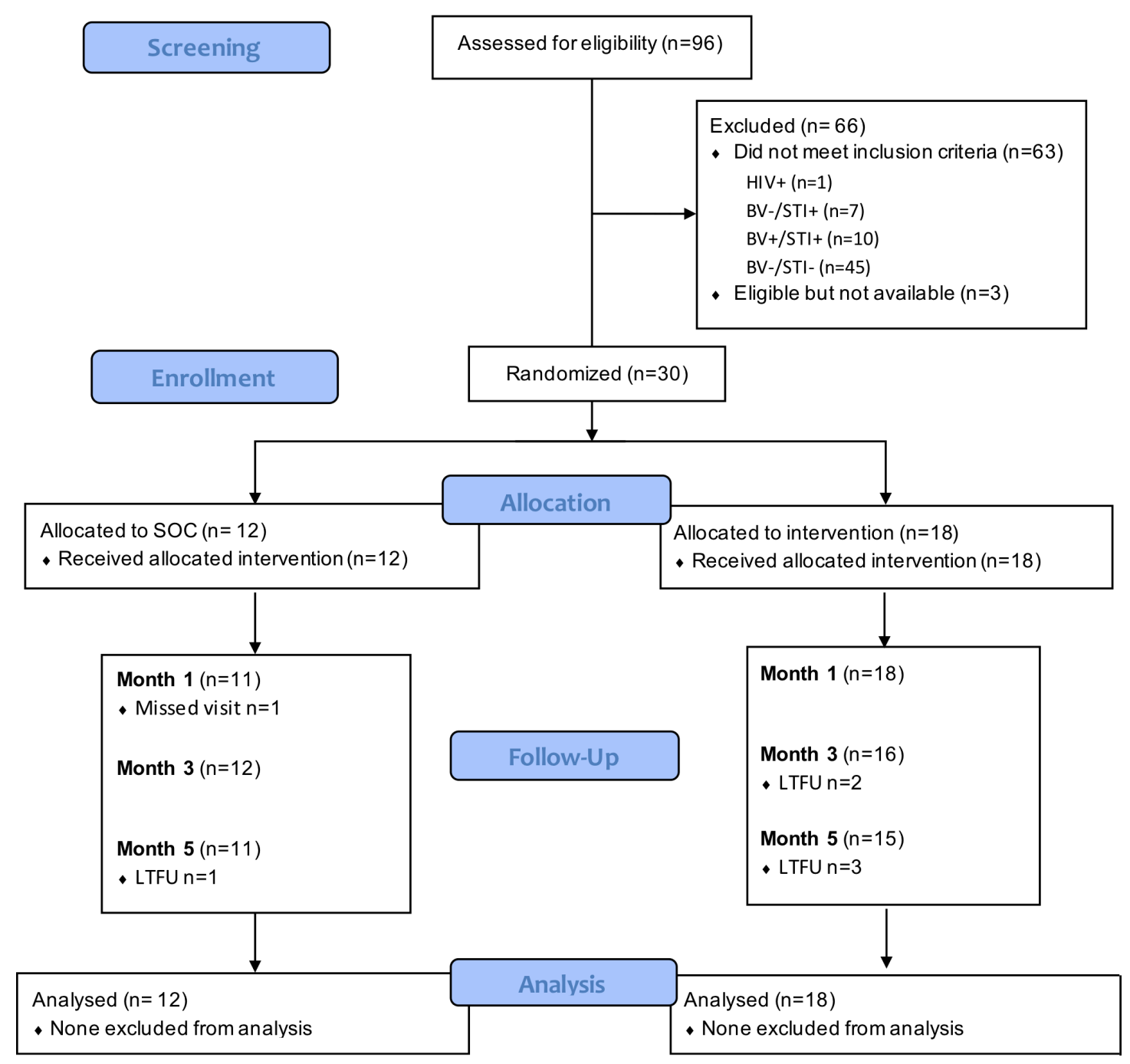

Figure 1. Consort diagram. A total of 96 women with symptomatic discharge were screened for eligibility Participants were tested for BV by Nugent Scoring on for STIs (including $C$. trachomatis, $T$. vaginalis, $M$. genitalium and $A$. vaginae) by Multiplex PCR. Eligible participants (BV positive but STI negative) were randomly assigned to the SOC (Metrogel ${ }^{\mathrm{TM}}$ only) or intervention arm (Metrogel ${ }^{\mathrm{TM}}$ plus Vagiforte ${ }^{\circledR}$ Plus Combo Pack). Follow-up visits took place 1, 3 and 5 months post-treatment. 


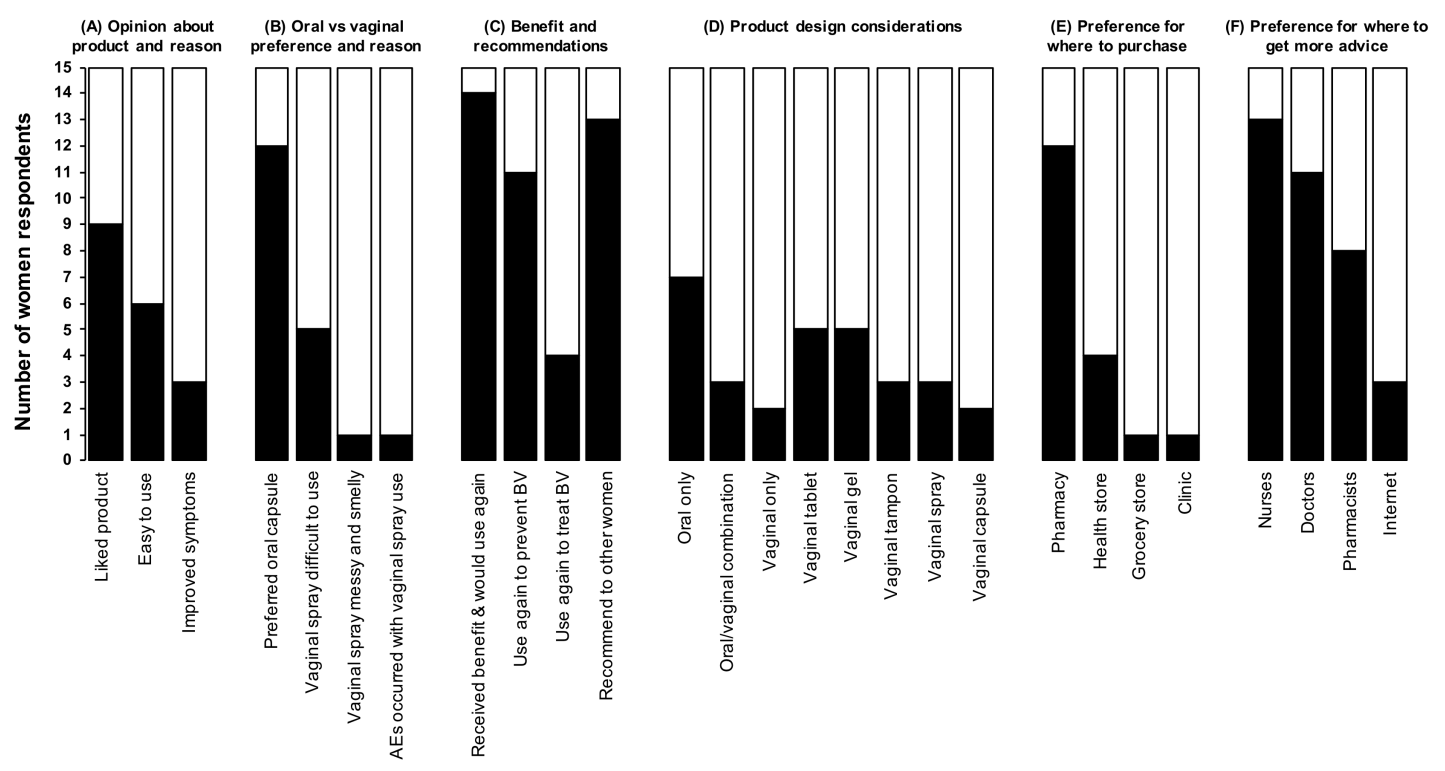

Figure 2. Acceptability and preference of probiotics for vaginal health. At the final visit, participants completed a questionnaire to assess their (A) opinion about the oral/vaginal probiotic they used during the trial, (B) why their preferred the oral or vaginal application, (C) their perceived benefits and whether they would use it again or recommend it to another woman, (D) their application preference for the development of a future probiotic for vaginal health, (E) where they would want to buy it and (F) from whom they would like to get advice regarding the use of probiotics for vaginal health.
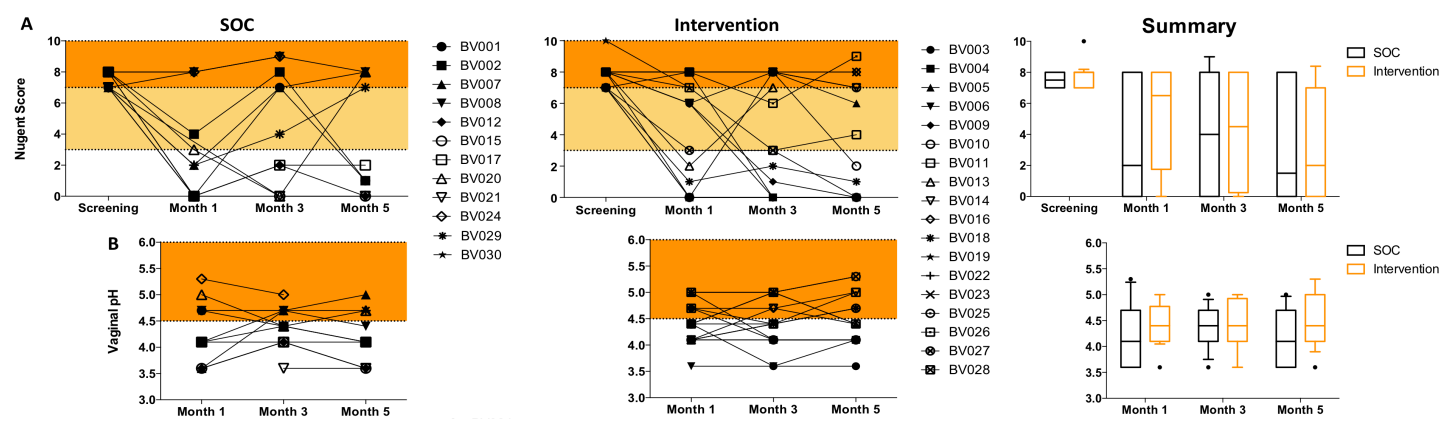

Figure 3. BV status and vaginal $\mathrm{pH}$ in the $\mathrm{SOC}$ and intervention group. (A) BV

status was determined by Nugent scoring at screening, and one, three and five-months post-treatment. Nugent Score 0-3 = BV negative (white area); 4-6= BV intermediate (yellow) and 7-10=BV positive (orange). (B) Vaginal $\mathrm{pH}$ was measured using colorfixed indicator strips one, three and five-months post-treatment. A vaginal $\mathrm{pH}<4.5$ (white area) is seen as protective. Each participant is represented by a symbol-coded dot, and the summaries show median and interquartile range. 


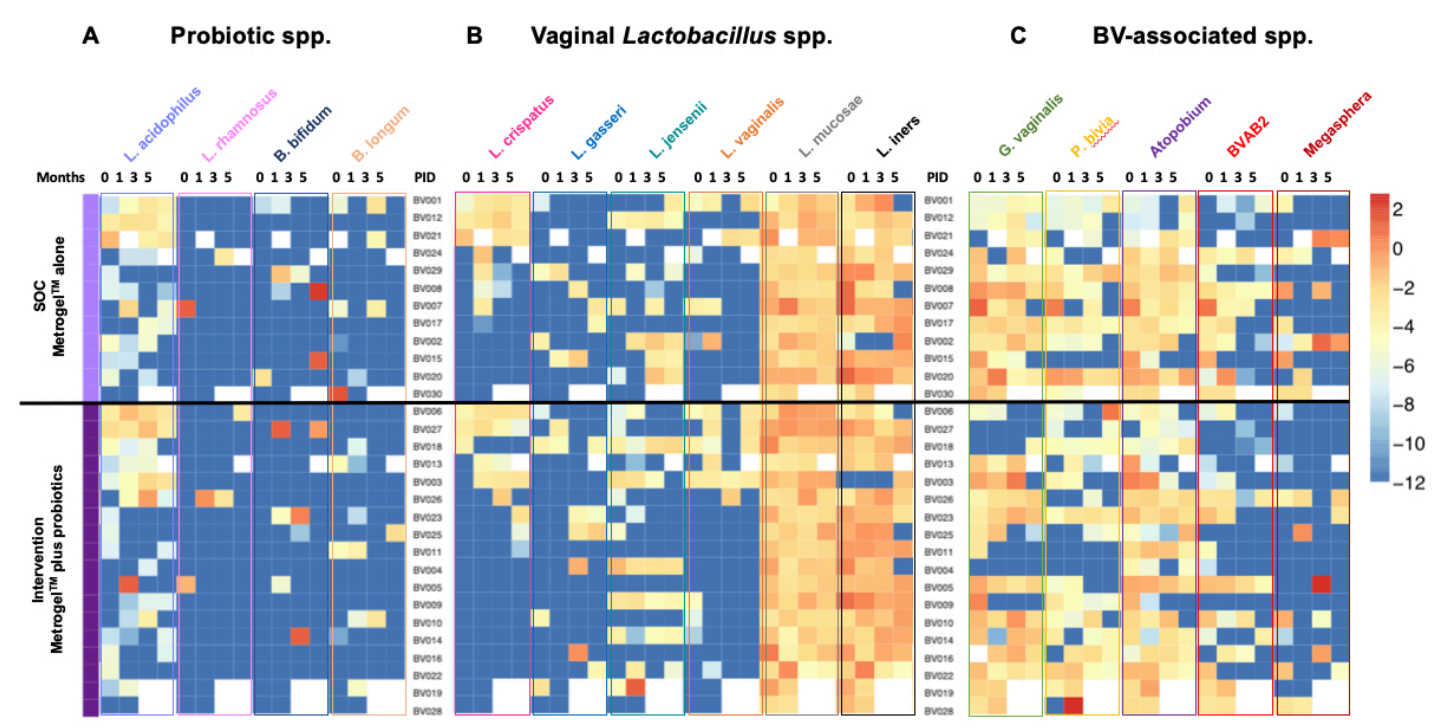

Figure 4. Quantities of vaginal bacterial species in the SOC and intervention group. (A) Bacterial species contained in Vagiforte ${ }^{\circledR}$ Plus Combo Pack, including $L$. acidophilus, L. rhamnosus, B. bifidum and B. longum, vaginal Lactobacillus spp., including L. crispatus, L. gasseri, L. jensenii, L. vaginalis, L. mucosae and L. iners (B) and BV-associated bacteria, including G. vaginalis, P bivia, Atopobium, BVAB2 and Megasphera (C) were measured by qPCR and normalised to total 16S rRNA gene concentration at month 0 (enrolment) and one, three and five months post-treatment. Values were log-transformed and supervised clustering was used to generate the heatmap. Each row shows one participant. Darkest blue indicates levels below detection limit. White data points indicate missing data. Light purple indicates participants from the SOC and dark purple participants from the intervention group. 

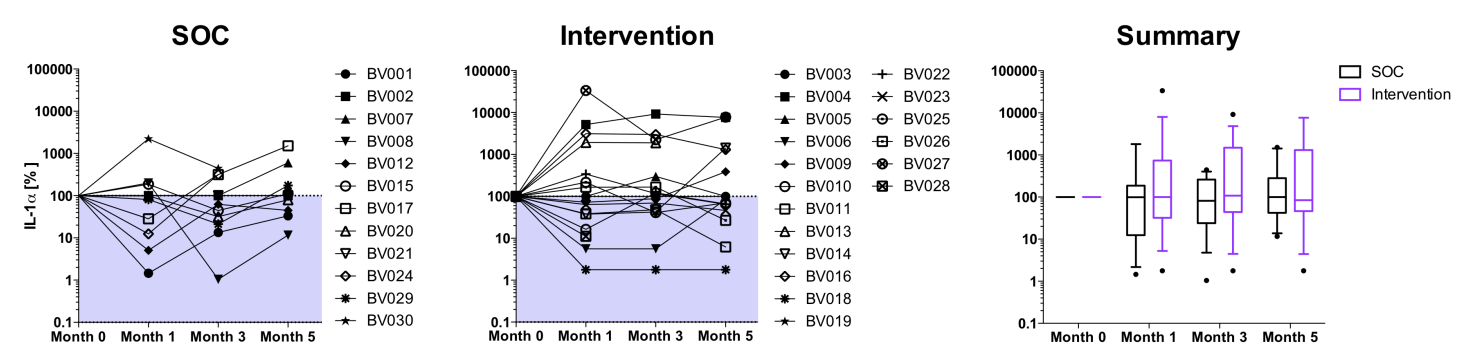

Figure 5. Levels of the inflammatory marker IL-1 $\alpha$ in the FGT of participants in the SOC and intervention arm. IL- $1 \alpha$ was measured by ELISA in FGT secretions of SOC and intervention group participants pre-treatment and 1, 3 and 5 months posttreatment. Each participant is represented by a symbol-coded dot. The percentages compared to the IL-1 $\alpha$ level measured pre-treatment (month 0) are displayed. The shaded area indicates a decrease in IL-1 $\alpha$ post-treatment. The summary shows the median and interquartile range.

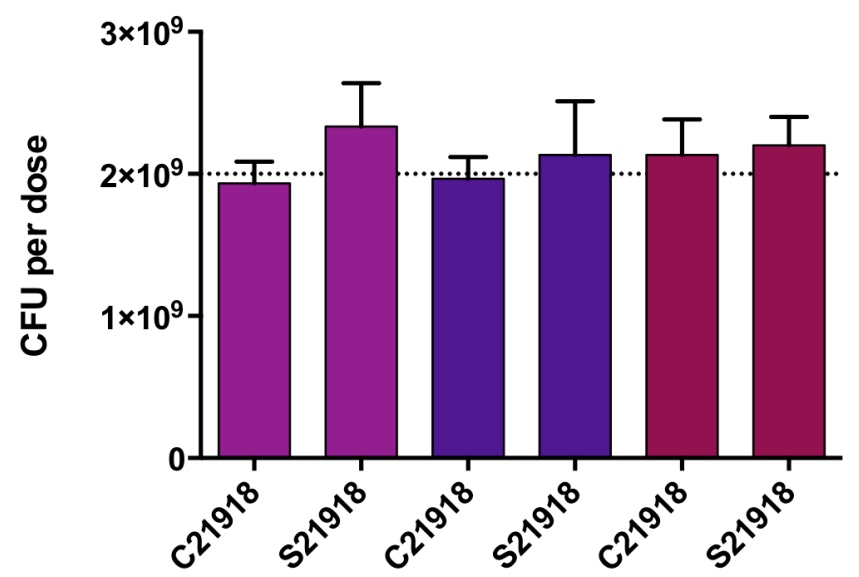

Additional Figure 1. Bacterial concentration per dose unit of Vagiforte ${ }^{\circledR}$ PLUS

Combo Pack. The CFU per dose of three boxes (pink, purple and red) of Vagiforte ${ }^{\circledR}$ Plus Combo Pack lot \#21918 containing oral capsules (C) and vaginal spray (S) was determined using serial dilutions and compared to the manufacturers claim of 2x109 CFU per dose (dotted line). 